\title{
Improved Student Learning Outcomes in Estimating the Total Price of Goods Using the Kahoot Application for Grade 2 Elementary School Students
}

\section{Erma Dhamayanti}

\author{
SD Negeri Margasari 07 \\ ermadhamay061212@gmail.com
}

\section{Article History}

accepted 01/11/2020

approved 08/11/2020

published 15/11/2020

\begin{abstract}
This study aims to improve student learning outcomes in estimating the total price of goods through the kahoot application. This research is a classroom action research conducted in three cycles. Each cycle consists of four stages, namely planning, implementing, observing, and reflecting. The research was conducted on the second grade students of SD Negeri Margasari 07 with a total of 20 students. This research was conducted at SD Negeri Margasari 07, Margasari District, Tegal Regency. When the study was conducted from October to November 2020. The results showed that student learning outcomes in estimating the total price of goods had increased. This can be seen from the average value of learning outcomes in the first cycle of 74 up to 80 in the second cycle. And in the third cycle the average value rose to 85 . The number of students who completed the first cycle was $70 \%$, in the second cycle it increased to $85 \%$ and in the third cycle it became $95 \%$. So it can be concluded that using the Kahoot application can improve the learning outcomes of grade II SD Negeri Margasar 07 in estimating the total price of goods.
\end{abstract}

\begin{abstract}
Abstrak
Penelitian ini bertujuan untuk meningkatkan hasil belajar siswa dalam menaksir jumlah harga barang melalui aplikasi kahoot. Penelitian ini merupakan penelitian tindakan kelas yang dilakukan sebanyak tiga siklus. Tiap siklus terdiri dari empat tahapan yaitu perencanaan, pelaksanaan, obsevasi, dan refleksi. Penelitian dilaksanakan pada siswa kelas II SD Negeri Margasari 07 dengan jumlah 20 siswa. Penelitian ini dilaksanakan di SD Negeri Margasari 07 Kecamatan Margasari Kabupaten Tegal. Waktu Penelitian dilaksanakan pada bulan Oktober sampai November 2020. Hasil penelitian menunujukan bahwa hasil belajar siswa dalam menaksir jumlah harga barang mengalami peningkatan. Hal ini dapat dilihat dari nilai rata-rata hasil belajar pada siklus I sebesar 74 naik menjadi 80 pada siklus II. Dan pada siklus III nilai rata-rata naik menjadi 85 . Jumlah siswa yang tuntas pada siklus I yaitu $70 \%$, pada siklus II naik menjadi $85 \%$ dan pada siklus III menjadi $95 \%$. Jadi dapat disimpulkan dengan menggunakan aplikasi Kahoot dapat meningkatkan hasil belajar siswa kelas II SD Negeri Margasar 07 dalam menaksir jumlah harga barang.
\end{abstract}

Kata kunci: Kahoot, Hasil belajar, Menaksir jumlah harga barang

Social, Humanities, and Education Studies (SHEs): Conference Series https://jurnal.uns.ac.id/shes

p-ISSN 2620-9284

e-ISSN 2620-9292 


\section{PENDAHULUAN}

COVID 19 memberikan dampak yang luar biasa di segala bidang, salah satunya pada bidang pendidikan. Dengan adanya COVID 19 ini membuat Mendikbud mengambil kebijakan pembelajaran jarak jauh atau daring sebagai upaya pencegahan penyebaran virus tersebut.

Berbagai permasalahan pembelajaran daring muncul karena belum meratanya jaringan internet di setiap daerah, tidak semua siswa memiliki laptop/smartphone. Selain itu kemampuan siswa dalam mengakses teknologi juga masih tergolong rendah. Meskipun demikian, guru tetap dituntut untuk melaksanakan pembelajaran seperti biasa sehingga dibutuhkan inovasi guru dalam melaksanakan pembelajaran daring dengan menarik, menyenangkan dan bermakna bagi siswa. Sehingga setiap guru dituntut untuk menguasai aplikasi pembelajaran berbasis daring. beberapa guru ada yang menggunakan WA Grup, Google meeting dan Zoom.

Berdasarkan pengamatan saat pembelajaran daring, hasil belajar siswa kelas II SD Negeri Margasari 07 dalam menaksir jumlah harga barang rendah. Hal ini dilihat dari nilai rata-rata hasil belajar siswa hanya 59. Dari 25 siswa hanya 14 siswa yang mendapat nilai lebih atau mencapai KKM. Dengan demikan dapat dinyatakan bahwa ketuntasan belajar yang dicapai dalam pembelajaran baru mencapai $56 \%$.

Banyak faktor yang menyebabkan rendahnya hasil belajar siswa dalam menaksir harga barang. Diantaranya karena guru dalam melaksanakan pembelajaran daring kurang menarik, kurangnya bimbingan guru pada siswa,kurangnya pemberian contoh dan latihan, sumber materi hanya dari buku pelajaran dan media yang digunakan hanya berupa gambar yang dikirim melalui Whatsapp grup.

Dari permasalahan tersebut, diperlukan upaya guru untuk mencari alternatif pemecahannya. Salah satu upaya yang dapat dilakukan adalah menggunakan media pembelajaran yang menarik yaitu Kahoot. Kahoot merupakan media pembelajaran berbasis permainan atau yang biasa dikenal game based learning (Putri, 2019). Permainan dilakukan secara online dan setiap siswa dapat memainkannya dengan gadget yang mereka miliki.

Dalam aplikasi Kahoot terdapat dua fitur yaitu for virtual classroom (teach) dan for self paced learning (assign). Virtual classroom (teach) dapat digunakan ketika guru dan siswa bertemu secara langsung di kelas dan dapat dimainkan baik secara individu (Classic) maupun kelompok (team mode). Self paced learning (assign) bisa dikerjakan kapan dan di mana saja sehingga guru dan murid tidak harus bertemu secara langsung.

Salah satu kelebihan Kahoot adalah soal-soal yang ada pada Kahoot memiliki alokasi waktu yang terbatas (Lime, 2019). Sehingga siswa dituntut untuk menjawab soal yang ditampilkan secara tepat, cepat dan teliti. Selain itu ketika mengerjakan juga bisa terdengar musik dan gambar yang dapat membangkitkan minat siswa. Dengan menggunakan aplikasi Kahoot diharapkan dapat meningkatkan hasil belajar siswa dalam menaksir jumlah harga barang.

Kahoot memiliki manfaat untuk meningkatkan persepsi peserta didik, meningkatkan kemampuan mengingat siswa, meningkatkan kemampuan transfer ilmu pembelajaran dan meningkatkan efektivitas pembelajaran (Khabidin, 2019)

Penelitian yang dilakukan oleh Setiawati, dkk (2018) menunjukan ada perbedaan hasil belajar yang signifikan antara kelas yang menggunakan game edukasi Kahoot dengan kelas yang menggunakan metode konvensional. Penelitian yang dilakukan Ningrum (2018) menunjukan penggunaan media kuis interaktif berbasis game edukasi kahoot! dapat meningkatkan hasil belajar.

Berdasarkan latar belakang di atas, Penulis memberi judul Penelitian Tindakan Kelas ini "Peningkatan Hasil Belajar Siswa Dalam Menaksir Jumlah Harga Barang Dengan Menggunakan Aplikasi Kahoot Pada Siswa Kelas II SD" 


\section{METODE}

Penelitian ini merupakan penelitian tindakan kelas yang dilaksanakan dalam tiga siklus. Setiap siklus terdiri dari tahap perencanaan, pelaksanaan, observasi dan refleksi. Subjek penelitian ini adalah siswa kelas II SD Negeri Margasari 07 Tahun 2020/2021 yang berjumlah 20 anak.

Teknik pengumpulan data yang di gunakan dalam penelitian ini adalah tes yang digunakan untuk mendapatkan data tentang hasil belajar siswa. Instrumen pengumpulan data yang digunakan dalam penelitian ini adalah butir soal evaluasi. Analisis data yang di gunakan dalam penelitian ini adalah analisis deskriptif komparatif untuk membandingkan hasil belajar melalui tes formatif/nilai ulangan harian antar siklus.

\section{Penerapan}

\section{HASIL DAN PEMBAHASAN}

Setiap siklus pada penelitian ini menggunakan aplikasi Kahoot. Penerapan penggunaan aplikasi Kahoot dalam pelaksanaan pembelajaran daring meliputi langkah-langkah sebagai berikut: (1) guru share screen menggunakan google meet (2) guru masuk pada https://kahoot.com dan melakukan log in terlebih dahulu, (3) selanjutnya akan nampak laman utama Kahoot lalu klik Kahoot. (4) setelah itu akan tampil soal-soal yang sudah dibuat oleh guru (5) pilih salah satu permainan soal yang akan dimainkan dan klik play.(6 terdapat dua pilihan fitur permainan yaitu for virtual classroom (Teach) dan for self paced learning (assign) (6) klik assign dan selanjutnya create dan muncul PIN. (7) Guru membuka https://kahoot.it dan memasukan PIN serta nama ke dalam permainan. (8) Permainanpun dimulai dan siswa secara bersamasama menjawab permainan kuis yang ditampilkan melalui share screen google meet. Dengan begitu siswa berpartisipasi aktif sehingga pembelajaran menjadi kondusif, interaktif dan menarik. (9) Guru memberikan PIN tersebut kepada siswa agar siswa dapat memainkannya sendiri menggunakan smartphone masing-masing di rumah.

\section{Hasil Belajar}

Hasil penelitian yang dilakukan pada siklus I sampai III menunjukan adanya peningkatan hasil belajar dalam menaksir jumlah harga barang. Peningkatan hasil belajar tersebut terlihat pada gambar di bawah ini.

\section{Gambar 1. Peningkatan hasil belajar}

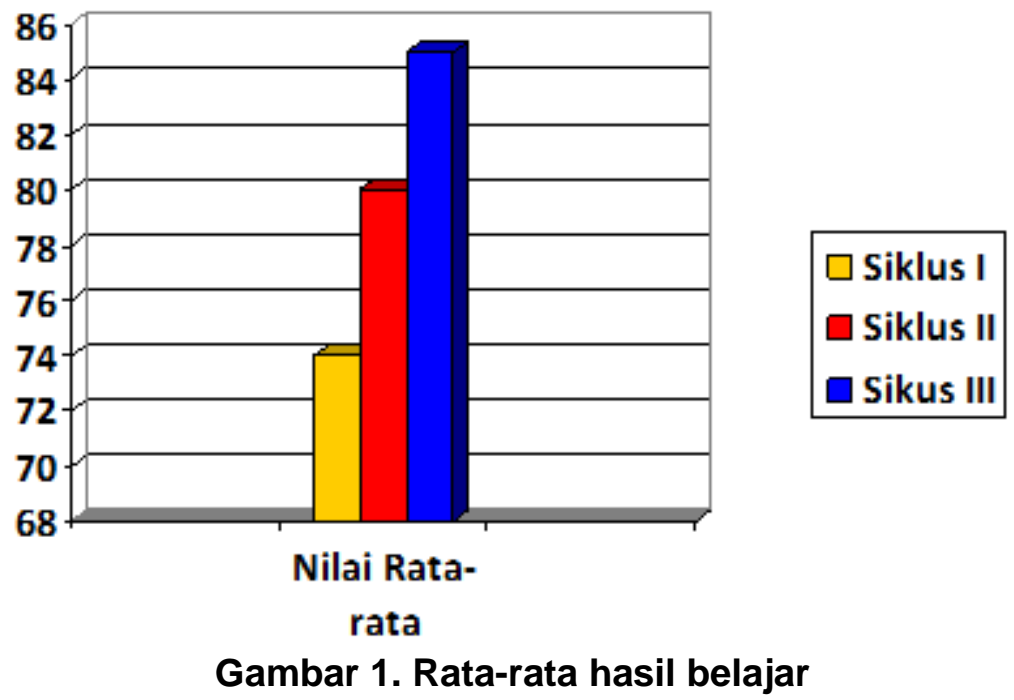


Berdasarkan gambar di atas dapat terlihat adanya peningkatan rata-rata hasil belajar pada tiap siklusnya. Pada siklus pertama rata-rata hasil belajar siswa meningkat menjadi 74 . Selanjutnya pada siklus II rata-rata hasil belajar siswa meningkat menjadi 80 dan meningkat lagi menjadi 85 pada siklus III.

Selain peningkatan hasil belajar, ketuntasan belajar pada tiap siklus juga mengalami peningkatan. Peningkatan keuntasan belajar dapat dilihat pada gambar di bawah ini.

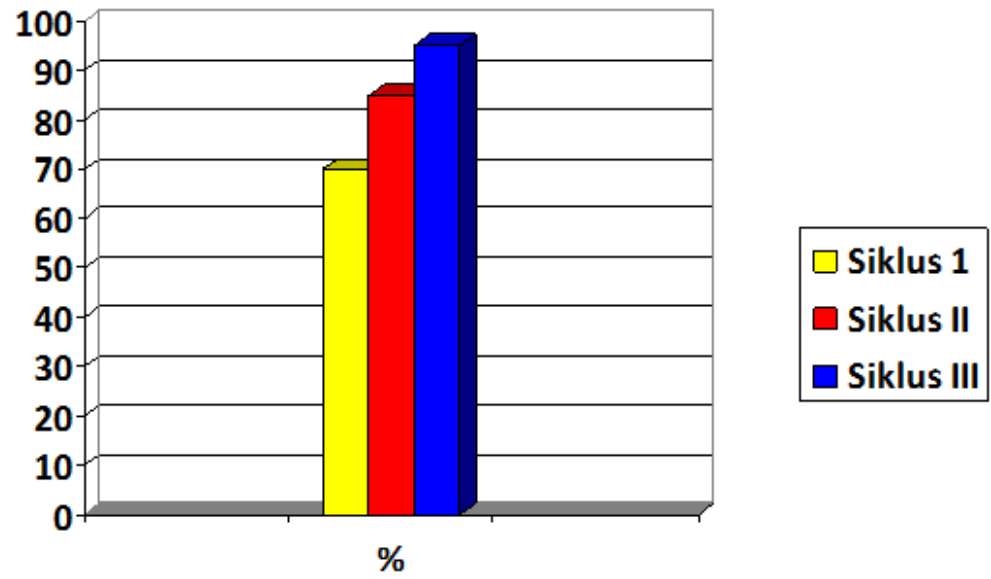

Ketuntasan

Gambar 2. Persentase ketuntasan belajar

Berdasarkan gambar tersebut dapat terlihat adanya peningkatan ketuntasan hasil belajar pada tiap siklusnya.pada siklus I ketuntasan belajar siswa dalam menaksir jumlah harga sebanyak $70 \%$ dan siklus II meningkat menjadi $85 \%$. Pada siklus III ketuntasan belajar meningkat lagi menjadi 95\%.

Berdasarkan analisis di atas dapat disimpulkan bahwa kegiatan pembelajaran menggunakan aplikasi Kahoot dapt meningkatkan hasil belajar siswa dalam menaksir jumlah harga barang. Secara umum Kahoot sangat mempengaruhi suasana belajar menjadi lebih menyenangkan. Kegiatan pembelajaran menggunakan Kahoot mampu menarik perhatian dan membuat siswa lebih fokus pada pembelajaran, sehingga hasil belajar siswa pun meningkat.

Peningkatan hasil belajar tersebut sesuai dengan hasil penelitian yang dilakukan oleh Wigati (2019) bahwa penggunaan Kahoot terbukti dapat meningkatkan hasil belajar matematika.

\section{SIMPULAN}

Berdasarkan hasil penelitian yang dilakukan pada siklus 1, 2, dan 3 dapat disimpulkan bahwa penggunaan aplikasi KAHOOT dapat meningkatkan hasil belajar siswa dalam menaksir harga sekumpulan barang yang ditandai dengan peningkatan persentase ketuntasan belajar siklus $170 \%$ dengan rata-rata hasil belajar 74 . Kemudian meningkat pada siklus 2 persentase ketuntasan belajar menjadi $85 \%$ dengan rata-rata hasil belajar menjadi 80 . Pada siklus 3 terjadi peningkatan lagi dengan persentase ketuntasan belajar 95\% dan rat-rata hasil belajar menjadi 85 .

Berdasarkan kesimpulan penelitian, maka dapat disarankan beberapa hal sebagai berikut: (1)Guru dapat menggunakan Kahoot sebagai media pembelajaran agar siswa lebih tertarik dalam pembelajaran sehingga hasil belajar meningkat, (2) Guru dapat meningkatkan kemampuan profesionalnya dengan menerapkan media pembelajaran berbasis teknologi di internet dalam kegiatan pembelajaran, (3) Sekolah 
hendaknya memberikan motivasi dan perhatian penuh atas ketersediaan media pembelajaran yang memungkinkan dapat dipenuhi.

\section{DAFTAR PUSTAKA}

Khabidin, 2019. Efektifitas Penerapan Aplikasi Kahoot Dalam Mengkondisikan Kelas Pada Mata Pelajaran Pendidikan Agama Islam Di SMP N 1 Pagentan Kabupaten Banjarnegara. https://dspace.uii.ac.id/handle/123456789/14126

Lime. 2018. Pemanfaatan media Kahoot pada proses pembelajaran model koopertif Tipe STAD ditinjau dari kerjasama dan hasil belajar siswa kelas VII-1 SMP Negeri 5 Yogyakarta Tahun ajaran 2017/2018. Skripsi http://repository.usd.ac.id/31078/2/141414034_full.pdf

Ningrum, G.D.K, 2018. Studi Penerapan Media Kuis Interaktif Berbasis Game Edukasi Kahoot! Terhadap Hasil Belajar Mahasiswa. Vox Edukasi: Jurnal IImiah IImu Pendidikan. 9(1)

Putri, B.R. (2019). Penggunaan Media Kahoot untuk meningkatkan hasil belajar IPS http://journal.unj.ac.id/unj/index.php/eips/article/view/14295 . Jurnal Edukasi IPS, 3(2)

Setiawati H.D,dkk (2018). Pengaruh Kahoot! Terhadap Hasil Belajar Siswa Kelas XI Di SMAN 1 Blitar. JKTP: Jurnal Kajian Teknologi Pendidikan, 1(4)

Wigati, S. (2019). Penggunaan Media Game Kahoot Untuk Meningkatkan Hasil Dan Minat

Belajar Matematika. https://www.researchgate.net/publication/338295662_PENGGUNAAN_MEDIA_G AME_KAHOOT_UNTUK_MENINGKATKAN_HASIL_DAN_MINAT_BELAJAR_M ATEMATIKA . Āksioma Jurnal Program Studi Pendidikan Matematika., 8(3) 